\title{
CHEMICAL PROPERTIES AND SIMILARITY OF HABITATS OF UTRICULARIA SPECIES IN LOWER SILESIA, POLAND
}

\author{
PIOTR KOSIBA
}

Department of Ecology and Nature Protection, Institute of Plant Biology, Wrocław University

Kanonia 6/8, 50-328 Wrocław, Poland

e-mail: kosibap@biol.uni.wroc.pl

(Received: January 14, 2004. Accepted: April 14, 2004)

\begin{abstract}
The study object consisted of 28 microhabitats of five Utricularia species localized in the Province of Lower Silesia, Poland. The aim of the study was to analyse the chemical properties of water and to present the differentiation of microhabitats in respect of their chemism, i.e., whether there are differences between the microhabitats, and which of the Utricularia species show the highest tolerance to the chemical properties of water. Analysed were the contents of $\mathrm{NO}_{2}^{-}, \mathrm{NO}_{3}^{-}, \mathrm{NH}_{4}^{+}, \mathrm{PO}_{4}^{-2}, \mathrm{~K}^{+}, \mathrm{Ca}^{+2}, \mathrm{Mg}^{+2}, \mathrm{Na}^{+}, \mathrm{Fe}^{+3}, \mathrm{SO}_{4}^{-2}$, total hardness of water, organic substance, $\mathrm{pH}$ and trophicity of water. The differentiation of microhabitats of Utricularia intermedia and U. minor appeared to be small, but much higher in case of $U$. vulgaris, $U$. australis and $U$. ochroleuca. The similarity of microhabitats has been determined by cluster analysis. The tree plot showed the least similarity of $U$. minor and $U$. intermedia, which occupy an extreme position in relation to microhabitats of the remaining species. Such a grouping suggests that this species is clearly distinct because of its connection with water properties.
\end{abstract}

KEY WORDS: Utricularia, microhabitat, trophicity, chemical properties of water, cluster analysis, similarity.

\section{INTRODUCTION}

Carnivorous plants are represented, among other, by bladderworts (genus Utricularia, family Lentibulariacae). The bladderworts are represented in Poland by five species: $U$. vulgaris L., U. australis R. BR., U. minor L., U. intermedia Hayne and $U$. ochroleuca R. W. Hartm. The sixth species, $U$. bremii Heer, was present several decades ago and is probably extinct (Zając, Zając 2001; Mirek et al. 2002). The number of localities of the particular Utricularia species differs considerably (Żukowski 1974; Zając, Zając 2001). A common species is $U$. vulgaris occurring frequently in the Lower Silesian Province (Fig. 1) (Żukowski 1974; Zając, Zając 2001). U. intermedia (Fig. 2), U.ochroleuca (Fig. 3) and U. australis (Fig. 4) are data deficient (DD) species (Kącki 2003). According to Zarzycki et al. (1992) U. ochroleuca like U. minor (Fig. 5) are most rare in Poland and are recognized as vulnerable (VU) (Kącki 2003). The position of U. bremii (Fig. 6) is uncertain and occurred, according to Żukowski (1974), decades ago in the vicinity of Zgorzelec and Lubań (Lower Silesia) and near Reszel (Mazurian Lake District).

The number of undiversified Utricularia localities in Poland (surface $312685 \mathrm{~km}^{2}$ ) according to the ATPOL Distribution Atlas, is the following: U. vulgaris - 896 localities, U. minor - 419, U. intermedia - 326, U. australis -
200, U. ochroleuca - 24 localities and in Lower Silesian Province (19 $\left.948 \mathrm{~km}^{2}\right)$ U. vulgaris -40 localities, U. minor - 19, U. intermedia - 10, U. australis - 13 and U. ochroleuca -3 localities.

Transformations and contamination of the environment are well known phenomena in result of intensive man's activity (Boyd 1968; Wiegleb et al. 1991; Smith et al. 1999). The impact of pollution on plants and their occurrence in Lower Silesia were investigated among others by Brej (1998), Fabiszewski, Brej (2000) and Fabiszewski, Kwiatkowski (1997, 2002), and the extinct, endangered, vulnerable and disappearing plant species in many regions of Poland are presented in Red Lists (Zarzycki et al. 1992; Kaźmierczakowa, Zarzycki 2001; Nowak, Spałek 2002; Kącki 2003). Therefore, due to the changing environmental conditions, it becomes necessary to estimate their resources, habitat conditions, not only of rare, but also common species (Kosiba 1990). Ecological studies constitute important circumstances for active protection of populations and their biotopes (Boyd 1968; Hutchinson 1975).

The aim of this study was to analyse the properties of water and to show the differentiation of microhabitat conditions in respect of chemical proprieties, and to find whether these microhabitats are similar between themselves, and which of the investigated species show the greatest tolerance in relation to water properties. 


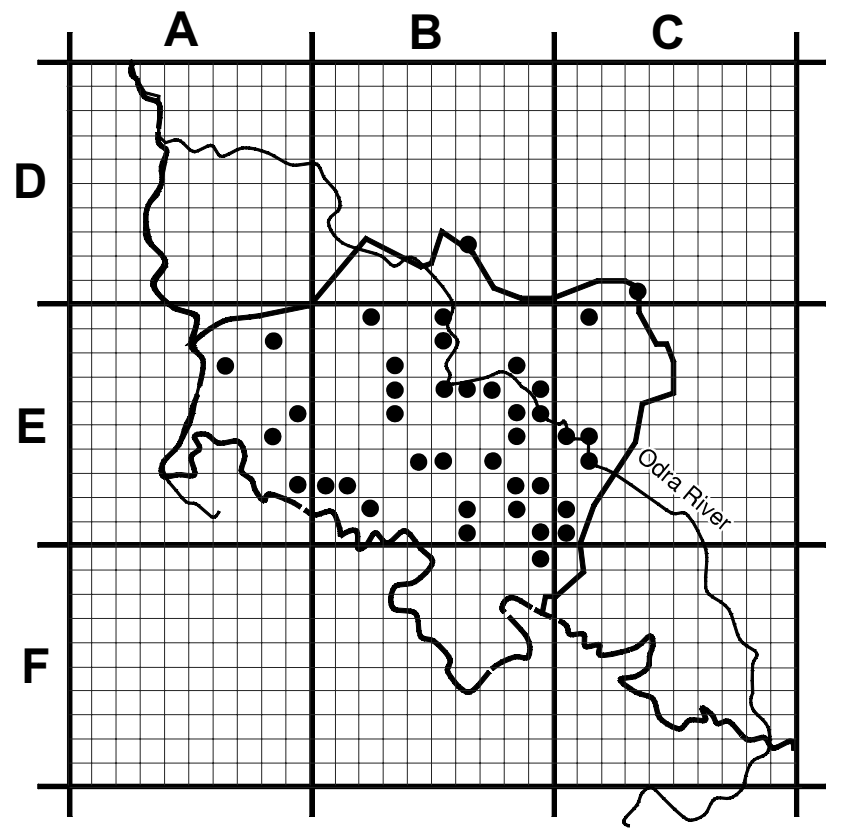

Fig. 1. Locality of undiversified sites of Utricularia vulgaris in the Province of Lower Silesia (according to Zając A. and Zając M. (eds). 2001. ATPOL Atlas).

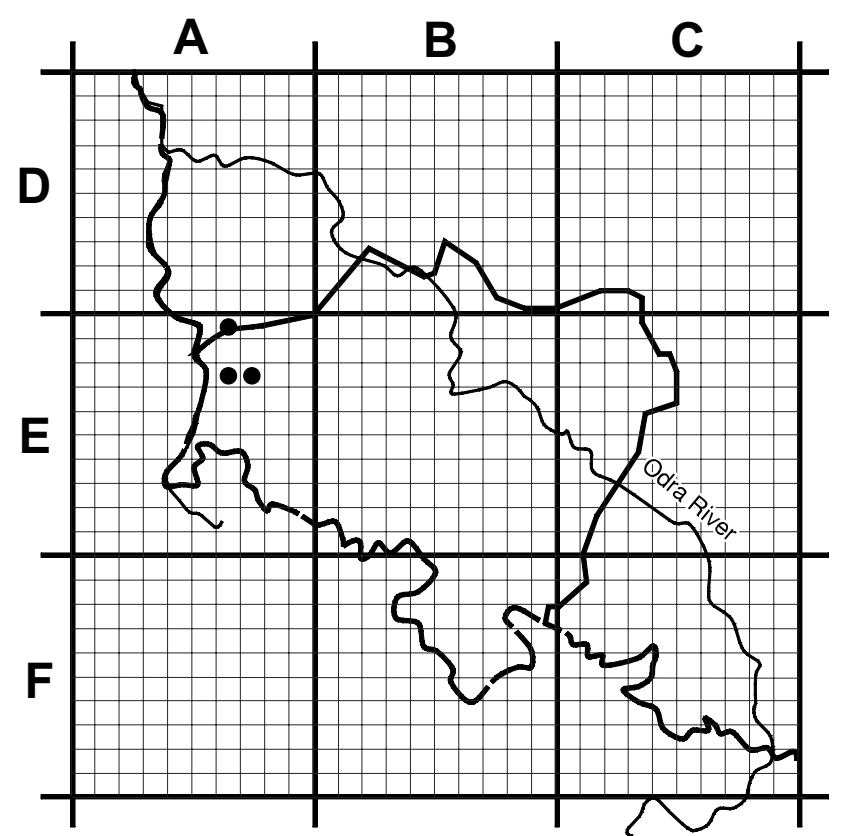

Fig. 3. Locality of undiversified sites of Utricularia ochroleuca in the Province of Lower Silesia (according to Zając A. and Zając M. (eds). 2001. ATPOL Atlas).

\section{MATERIAL AND METHODS}

The investigations were carried out in field in the Province of Lower Silesia. Figure 7 presents the situation of Lower Silesia in Poland according to the grid used in the ATPOL Distribution Atlas (Zając, Zając 2001). Twenty eight microhabitats were selected, and the study object consisted of five species: $U$. vulgaris, $U$. intermedia, $U$. ochroleuca, $U$. australis and $U$. minor (Table 1, Fig. 8).

All the microhabitats occur in one local climatic zone. This allows to compare the microhabitats in respect of their

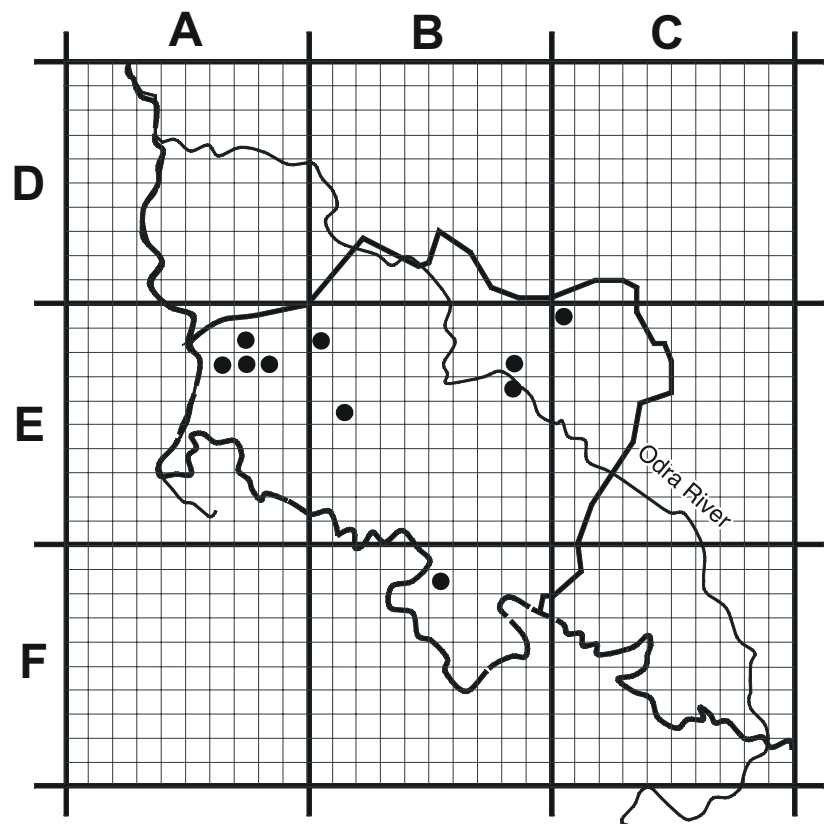

Fig. 2. Locality of undiversified sites of Utricularia intermedia in the Province of Lower Silesia (according to Zając A. and Zając M. (eds). 2001 ATPOL Atlas).

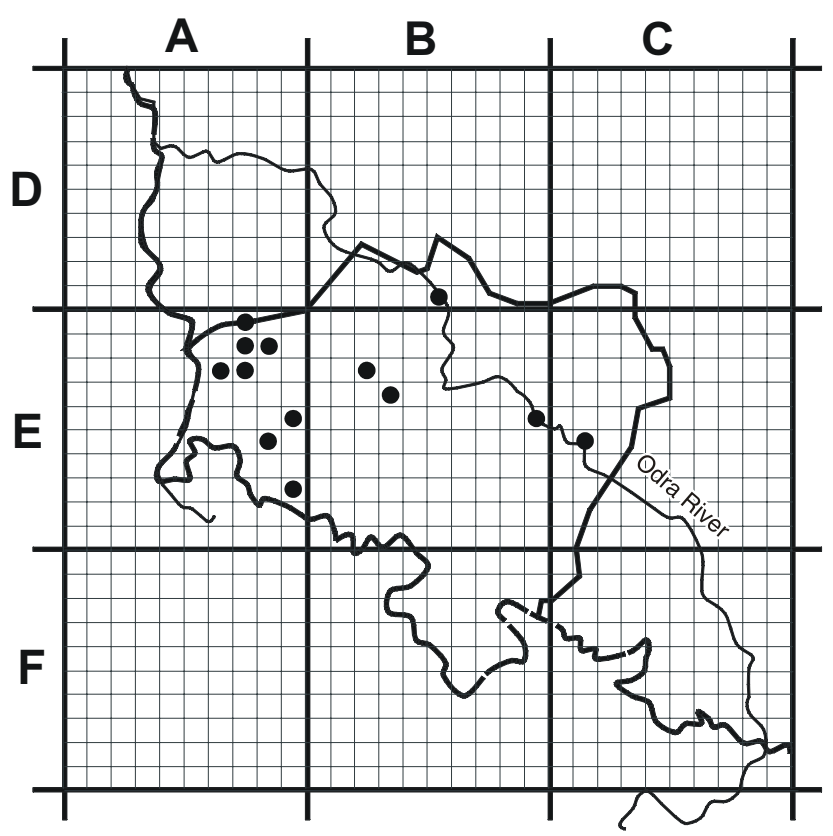

Fig. 4. Locality of undiversified sites of Utricularia australis in the Province of Lower Silesia (according to Zając A. and Zając M. (eds). 2001. ATPOL Atlas).

chemical characteristics (Herpin et al. 1996). The water samples were collected at the same time from various water reservoirs and were subjected to the same chemical analyses. The contents of $\mathrm{NO}_{2}^{-}, \mathrm{NO}_{3}^{-}, \mathrm{NH}_{4}^{+}, \mathrm{PO}_{4}^{-3}, \mathrm{~K}^{+}, \mathrm{Ca}^{+2}$, $\mathrm{Mg}^{+2}, \mathrm{Na}^{+}, \mathrm{Fe}^{+3}, \mathrm{SO}_{4}^{-2}$, total hardness of water, organic substance and $\mathrm{pH}$ were analysed according to the principles of Hermanowicz et al. (1999). On the basis of results the following statistical analyses were performed: mean, standard deviation, variability coefficient, one-way analysis of variance (ANOVA), similarity of microhabitats in respect of chemical properties determined by the method of cluster 


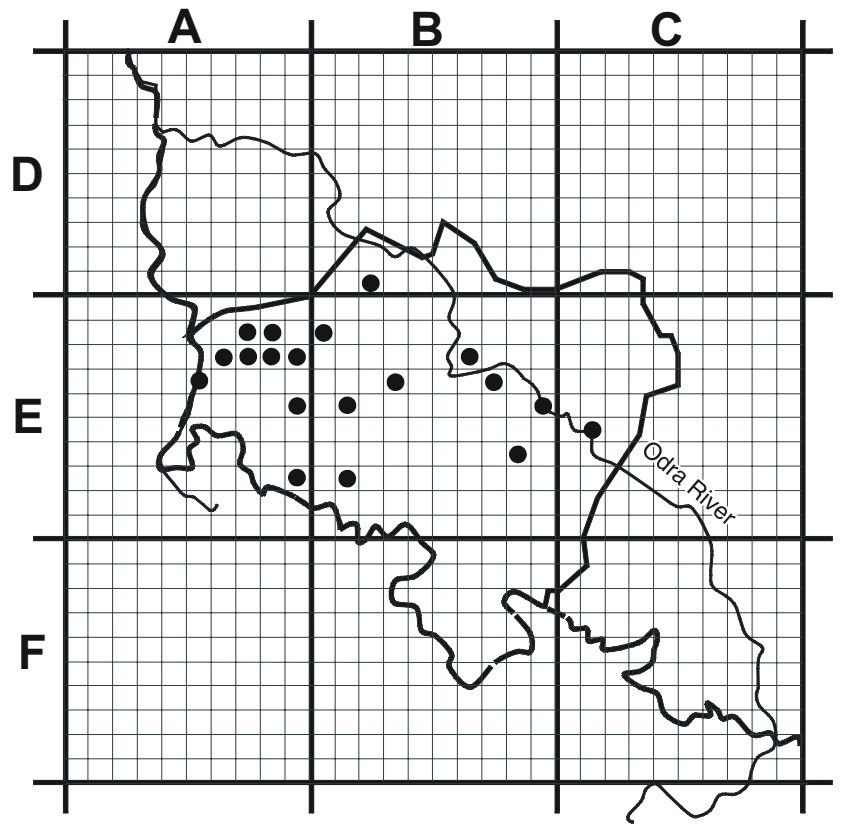

Fig. 5. Locality of undiversified sites of Utricularia minor in the Province of Lower Silesia (according to Zając A. Zając M. (eds). 2001. ATPOL Atlas).

analysis, and a hierarchical tree plot was drawn using the single linkage method (nearest neighbour), basing on matries of Euclidean distance $(\mathrm{x}, \mathrm{y})=\left\{\Sigma_{\mathrm{i}}\left(\mathrm{x}_{\mathrm{i}}-\mathrm{y}_{\mathrm{i}}\right)^{2}\right\}^{1 / 2}$ (Zając 1994; Legendre, Legendre 1998).

For statistical analysis of results the computer program Statistica 6.1 was used (StatSoft, Inc. 2003).

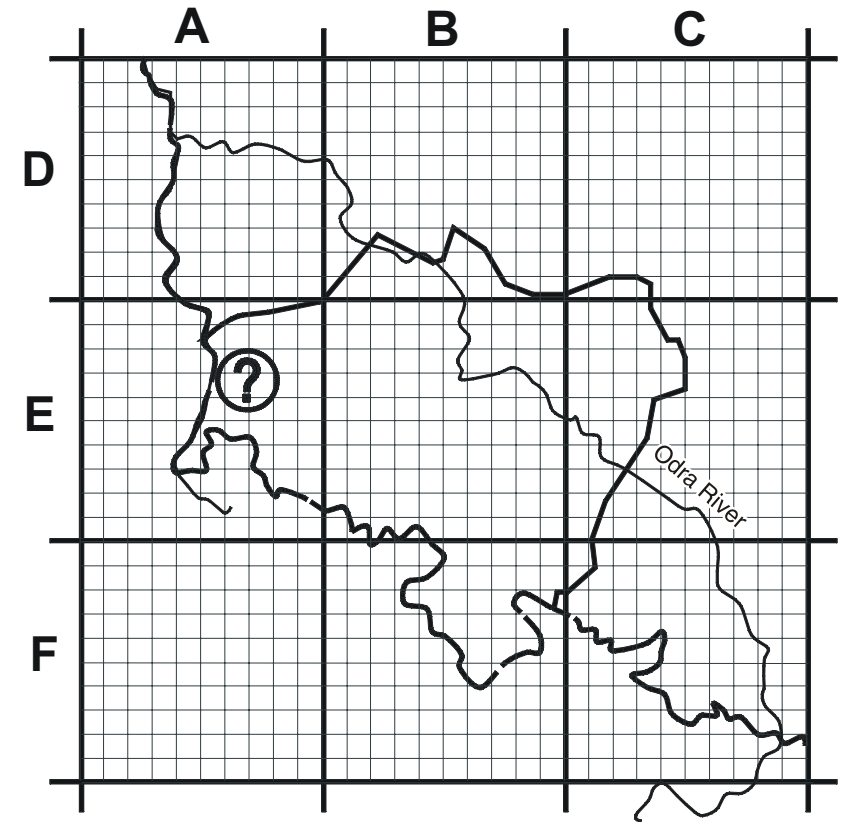

Fig. 6. Locality of undiversified sites of Utricularia Bremii in the Province of Lower Silesia (according to Zając A. and Zając M. (eds). 2001. ATPOL Atlas).

\section{RESULTS AND DISSCUSION}

The microhabitats of the examined bladderworts are localized in Province of Lower Silesia (Figs 7, 8). The Figures 1-6 show the presence of the taxon and the situation of undiversified localities in units of $10 \times 10 \mathrm{~km}$ according to

TABLE 1. The designation of examined microhabitats of Utricularia species according to ATPOL grid squares.

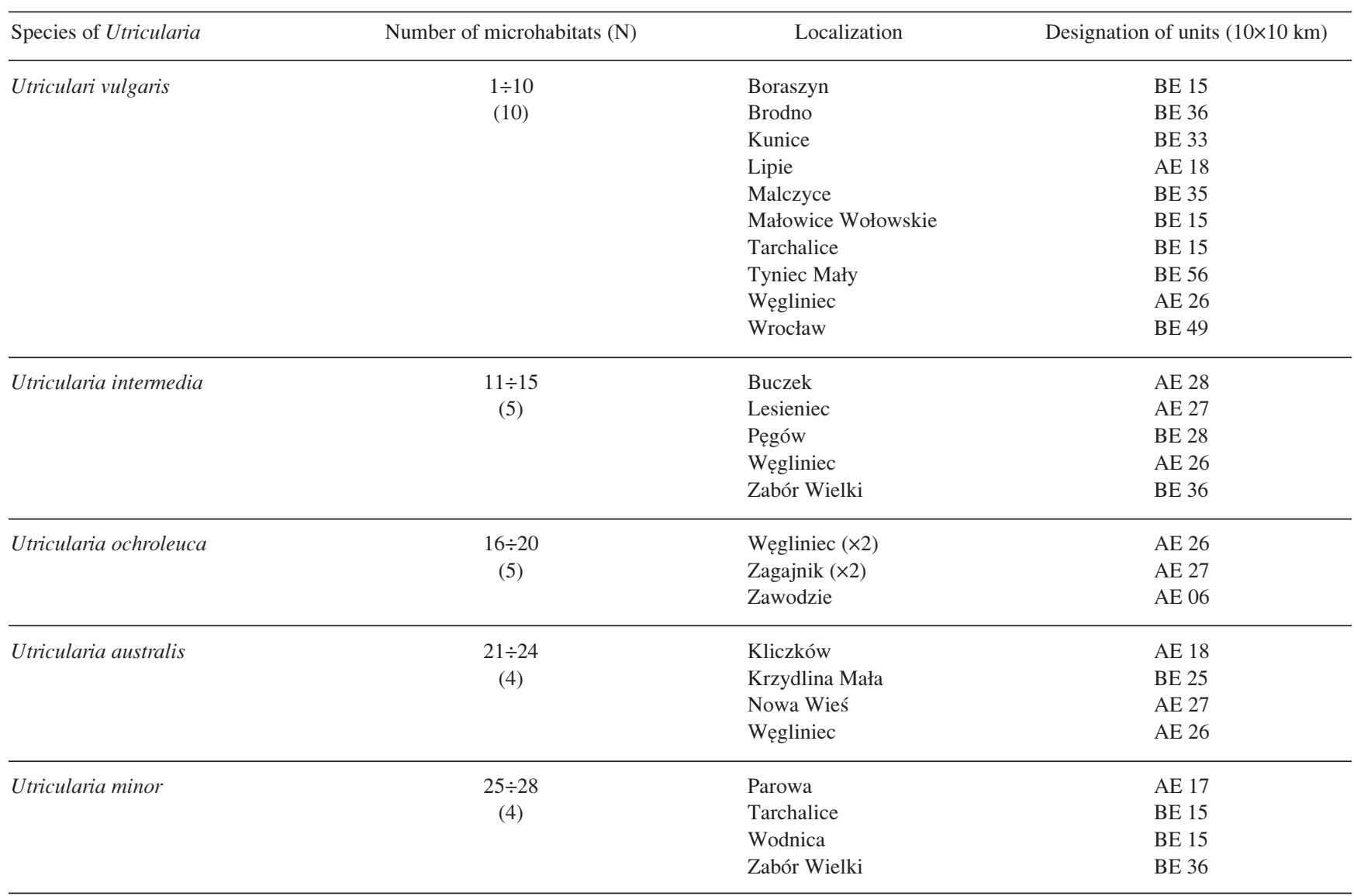




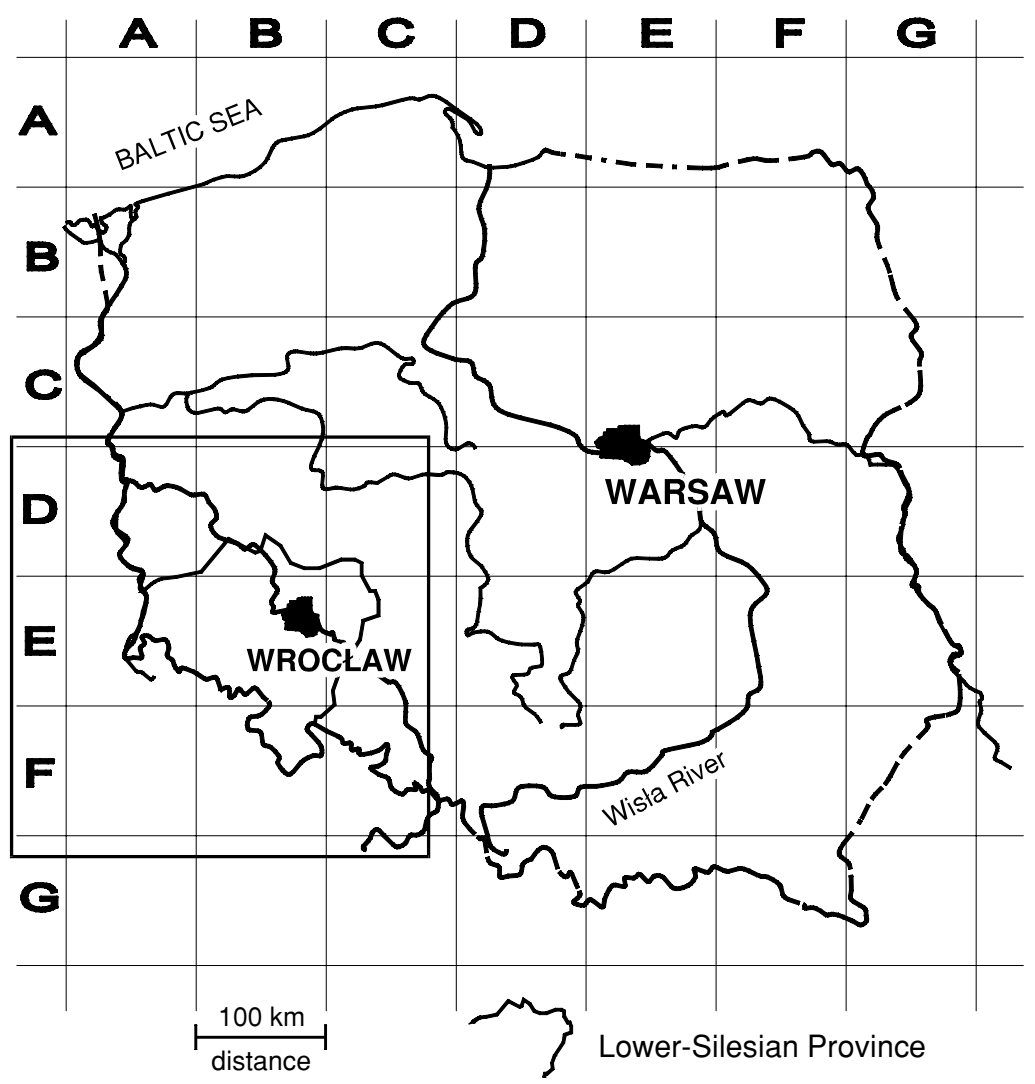

Fig. 7. Situation of the Province of Lower Silesia in Poland.

the ATPOL Atlas (Zając, Zając 2001). The number of undiversified localities in relation to species differ considerably, e.g.: $U$. vulgaris $40, U$. minor 19 , U. intermedia 10 , $U$. australis 13 and $U$. ochroleuca 3 localities. The number of localities of $U$. bremii is unknown.
The characteristics of the investigated microhabitats of bladderworts in respect of chemical proprieties are shown in Table 2. They differ significantly in respect of $\mathrm{NO}_{2}^{-}$, $\mathrm{NO}_{3}^{-}, \mathrm{NH}_{4}^{+}, \mathrm{K}^{+}, \mathrm{Fe}^{+3}, \mathrm{SO}_{4}^{-2}$, organic substance and $\mathrm{pH}$. According to Wetzel (1983), the chemism of water reflects

TABLE 2. Chemical properties of water of examined microhabitats of Utricularia species.

\begin{tabular}{|c|c|c|c|c|c|c|c|c|c|c|c|c|c|}
\hline \multirow{3}{*}{ Microhabitats } & $\mathrm{NO}_{2}^{-}$ & $\mathrm{NO}_{3}^{-}$ & $\mathrm{NH}_{4}^{+}$ & $\mathrm{PO}_{4}^{-3}$ & $\mathrm{~K}^{+}$ & $\mathrm{Ca}^{+2}$ & $\mathrm{Mg}^{+2}$ & $\mathrm{Na}^{+}$ & $\mathrm{Fe}^{+3}$ & $\mathrm{SO}_{4}^{-2}$ & $\begin{array}{l}\text { Organic } \\
\text { substance }\end{array}$ & $\begin{array}{l}\text { Hardness } \\
\text { of water }\end{array}$ & \multirow[t]{2}{*}{$\mathrm{pH}$} \\
\hline & \multicolumn{11}{|c|}{$\left[\mathrm{mg} / \mathrm{dm}^{3}\right]$} & {$\left[{ }^{\circ} \mathrm{HD}\right]$} & \\
\hline & \multicolumn{13}{|c|}{ mean \pm SD. variability coefficient $[\%]$ and ANOVA test } \\
\hline $\begin{array}{l}\text { Utricularia vulgaris } \\
\text { A }(1 \div 10)\end{array}$ & $\begin{array}{c}0.02 \pm 0.01 \\
58.5\end{array}$ & $\begin{array}{c}0.68 \pm 0.53 \\
77.8\end{array}$ & $\begin{array}{c}0.69 \pm 0.60 \\
87.5\end{array}$ & $\begin{array}{c}0.47 \pm 0.27 \\
57.5\end{array}$ & $\begin{array}{c}1.17 \pm 0.56 \\
48.3\end{array}$ & $\begin{array}{c}42.78 \pm 17.64 \\
41.2\end{array}$ & $\begin{array}{c}8.36 \pm 4.29 \\
51.4\end{array}$ & $\begin{array}{c}3.10 \pm 1.71 \\
55.1\end{array}$ & $\begin{array}{c}0.31 \pm 0.17 \\
55.4\end{array}$ & $\begin{array}{c}16.55 \pm 5.64 \\
34.1\end{array}$ & $\begin{array}{c}2.73 \pm 0.77 \\
28.2\end{array}$ & $\begin{array}{c}4.49 \pm 1.54 \\
34.3\end{array}$ & $\begin{array}{c}7.15 \pm 1.67 \\
23.4\end{array}$ \\
\hline $\begin{array}{l}\text { Utricularia ochroleuca } \\
\text { C }(16 \div 20)\end{array}$ & $\begin{array}{c}0.03 \pm 0.01 \\
53.8\end{array}$ & $\begin{array}{c}1.90 \pm 0.85 \\
44.7\end{array}$ & $\begin{array}{c}0.61 \pm 0.29 \\
47.7\end{array}$ & $\begin{array}{c}0.44 \pm 0.29 \\
66.2\end{array}$ & $\begin{array}{c}0.70 \pm 0.30 \\
43.6\end{array}$ & $\begin{array}{c}35.53 \pm 12.10 \\
34.1\end{array}$ & $\begin{array}{c}6.19 \pm 1.93 \\
31.1\end{array}$ & $\begin{array}{c}2.45 \pm 0.86 \\
35.1\end{array}$ & $\begin{array}{c}0.66 \pm 0.55 \\
84.2\end{array}$ & $\begin{array}{c}21.77 \pm 5.51 \\
25.3\end{array}$ & $\begin{array}{c}4.53 \pm 2.04 \\
45.0\end{array}$ & $\begin{array}{c}2.92 \pm 1.41 \\
48.3\end{array}$ & $\begin{array}{c}6.05 \pm 0.73 \\
12.1\end{array}$ \\
\hline $\begin{array}{l}\text { Utricularia australis } \\
\text { D }(21 \div 24)\end{array}$ & $\begin{array}{c}0.04 \pm 0.01 \\
21.4\end{array}$ & $\begin{array}{c}1.69 \pm 0.37 \\
21.9\end{array}$ & $\begin{array}{c}1.58 \pm 0.42 \\
26.6\end{array}$ & $\begin{array}{c}0.34 \pm 0.14 \\
41.2\end{array}$ & $\begin{array}{c}0.60 \pm 0.31 \\
51.3\end{array}$ & $\begin{array}{c}32.15 \pm 14.60 \\
45.4\end{array}$ & $\begin{array}{c}5.92 \pm 1.21 \\
20.4\end{array}$ & $\begin{array}{c}2.21 \pm 0.67 \\
30.4\end{array}$ & $\begin{array}{c}0.54 \pm 0.38 \\
71.3\end{array}$ & $\begin{array}{c}15.31 \pm 4.66 \\
30.5\end{array}$ & $\begin{array}{c}5.87 \pm 1.84 \\
31.3\end{array}$ & $\begin{array}{c}4.73 \pm 3.07 \\
64.9\end{array}$ & $\begin{array}{c}6.20 \pm 0.84 \\
13.6\end{array}$ \\
\hline $\begin{array}{l}\text { Utricularia minor } \\
\text { E }(25 \div 28)\end{array}$ & $\begin{array}{c}0.05 \pm 0.02 \\
30.2\end{array}$ & $\begin{array}{c}1.64 \pm 0.43 \\
26.3\end{array}$ & $\begin{array}{c}1.27 \pm 0.52 \\
40.9\end{array}$ & $\begin{array}{c}0.11 \pm 0.03 \\
27.3\end{array}$ & $\begin{array}{c}1.25 \pm 0.47 \\
37.8\end{array}$ & $\begin{array}{c}38.45 \pm 11.23 \\
29.2\end{array}$ & $\begin{array}{c}7.31 \pm 1.48 \\
20.2\end{array}$ & $\begin{array}{c}3.05 \pm 1.03 \\
33.8\end{array}$ & $\begin{array}{c}0.51 \pm 0.18 \\
34.6\end{array}$ & $\begin{array}{c}41.09 \pm 11.78 \\
28.7\end{array}$ & $\begin{array}{c}5.23 \pm 0.83 \\
15.8\end{array}$ & $\begin{array}{c}4.82 \pm 0.97 \\
20.1\end{array}$ & $\begin{array}{c}6.05 \pm 0.46 \\
7.6\end{array}$ \\
\hline $\mathrm{F}$ & $5.17^{\star}$ & $3.93^{*}$ & $3.26^{*}$ & 1.70 & $3.08^{*}$ & 1.32 & 0.43 & 1.82 & $5.96^{*}$ & $16.04^{*}$ & $15.82^{*}$ & 0.84 & $9.59^{*}$ \\
\hline $\mathrm{F}_{(0.05 ; 4.23)}$ & & & & & & & 2.80 & & & & & & \\
\hline
\end{tabular}

* - statistically significant when: $\mathrm{F}>\mathrm{F}_{(0.05 ; 4.23)}$ 


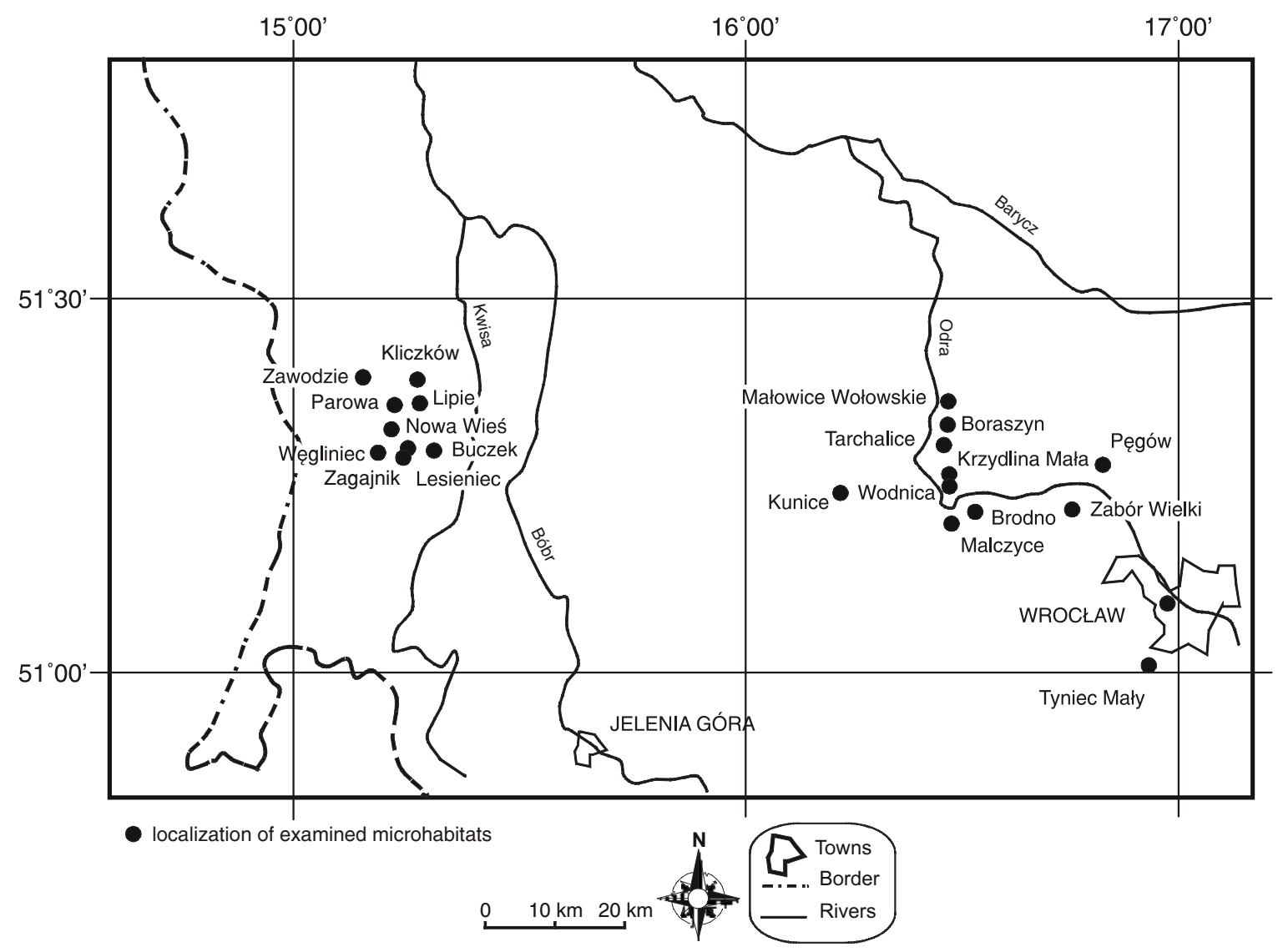

Fig. 8. Localization of examined microhabitats of Utricularia species.

its trophic status. Basing on results obtained by Pip (1979, 1984), Weigleb (1991) the waters analysed in the present paper are in most cases eutrophic (microhabitat 1-10 and 16-24), seldom dystrophic ones (microhabitat 11-15 and 25-28). In our case it was found that $U$. vulgaris, U. ochroleuca and $U$. australis prefer eutrophic waters, whereas $U$. minor and $U$. intermedia exist usually in dystrophic waters, which are characterized by the lowest $\mathrm{pH}$ and the highest contents of $\mathrm{NO}_{2}^{-}, \mathrm{SO}_{4}^{-2}$, as well as organic substance. These results find confirmation in earlier investigations on habitat conditions of bladderworts (Kosiba, Sarosiek 1989; Kosiba 1992a, c, 1993). This differentiation within species is slight for $U$. intermedia and $U$. minor. A greater differentiation occurs between species. On the basis of the variability coefficient the differentiation of microhabitats of $U$. intermedia and $U$. minor appeared to be small, respectively from $11.9 \%$ for $\mathrm{pH}$ to $44.0 \%$ for $\mathrm{K}^{+}$and from $7.6 \%$ for $\mathrm{pH}$ to 40.9 for $\mathrm{NH}^{+}$, but much higher in microhabitats of $U$. vulgaris, $U$. australis and $U$. Ochroleuca, respectively suitable from $23.4 \%$ for $\mathrm{pH}$ to $87.5 \%$ for $\mathrm{NH}_{4}^{+}$, from $13.6 \%$ for $\mathrm{pH}$ to $71.3 \%$ for $\mathrm{Fe}^{+3}$ and from $12.1 \%$ for $\mathrm{pH}$ to $84.2 \%$ for $\mathrm{Fe}^{+3}$ (Table 2).

On the basis of results, using the method of cluster analysis (Table 3), a hierarchical tree plot was constructed (Fig. 9), presenting the similarity of the investigated microhabitats. It shows the least similarity of $U$. intermedia and $U$. minor microhabitats, which take extreme positions and are characterized by the lowest $\mathrm{pH}$ and the highest contents of $\mathrm{NO}_{2}^{-}, \mathrm{SO}_{4}^{-2}$, organic substance and lower variability range of water properties in relation to the microhabitats of the remaining species, which again show a higher similarity between them. These microhabitats form seperate ecological types in respect of water chemism. Microhabitats of $U$. vulgaris, and $U$. ochroleuca populations form another group, characterized by the lowest contents of $\mathrm{NO}_{2}^{-}, \mathrm{NH}_{4}^{+}$, $\mathrm{SO}_{4}^{-2}$, organic substance, higher $\mathrm{pH}$ and a wide range of variability of water properties. In this group of similarity there occur microhabitats of $U$. australis, which are characterized by a lower contents of $\mathrm{NO}_{2}^{-}, \mathrm{Fe}^{+3}$, organic substance, $\mathrm{pH}$ and average values in most of the remaining chemical elements. Such grouping of Utricularia microhabitats suggests, that the particular analysed species are bound with water chemism. This was confirmed by investigations of Seddon (1972) and Wiegleb (1978a, b, 1981), who found relations between plant composition and chemism of water. This makes the ground for identification of ecological formations of different plant species and the knowledge on trophic requirements and tolerance of plants (Roman et al. 2001), and allows to conclude on the trophic level of water (Roy et al. 1992). Eutrophication, urbanization and contamination of the environment enrich the water by biogenic and anthropogenic elements. These factors cause stress, are highly significant for plants, and in consequence generate changes in plant communities (Roy et al. 1992; Murphy 2002). This shows that the analysis of trophic state of water is necessary, because the use of one or a few criteria may result in a distorted picture of the trophic state (Moiseenko et al. 2001). Species of a high tolerance to che- 
TABLE 3. Amalgamation schedule of examined microhabitats of Utricularia species.

\begin{tabular}{|c|c|c|c|c|c|c|c|c|c|c|c|c|c|c|c|c|c|c|c|c|c|c|c|c|c|c|c|c|}
\hline \multirow{2}{*}{$\begin{array}{l}\text { Linkage } \\
\text { distance }\end{array}$} & \multicolumn{28}{|c|}{ No of microhabitat } \\
\hline & $\begin{array}{l}\text { U.v. } \\
\text { (1) }\end{array}$ & $\begin{array}{l}\text { U.v. } \\
\text { (2) }\end{array}$ & $\begin{array}{l}\text { U.v. } \\
\text { (3) }\end{array}$ & $\begin{array}{l}\text { U.v. } \\
\text { (4) }\end{array}$ & $\begin{array}{l}\text { U.V. } \\
\text { (5) }\end{array}$ & $\begin{array}{l}\text { U.v. } \\
\text { (6) }\end{array}$ & $\begin{array}{l}\text { U.v. } \\
\text { (7) }\end{array}$ & $\begin{array}{l}\text { U.v. } \\
\text { (8) }\end{array}$ & $\begin{array}{l}\text { U.v. } \\
\text { (9) }\end{array}$ & $\begin{array}{l}\text { U.v. } \\
\text { (10) }\end{array}$ & $\begin{array}{l}\text { U.i. } \\
\text { (11) }\end{array}$ & $\begin{array}{l}\text { U.i. } \\
\text { (12) }\end{array}$ & $\begin{array}{l}\text { U.i. } \\
(13\end{array}$ & $\begin{array}{l}\text { U.i. } \\
\text { (14) }\end{array}$ & $\begin{array}{l}\text { U.i. } \\
\text { (15) }\end{array}$ & $\begin{array}{l}\text { U.o. } \\
\text { (16) }\end{array}$ & $\begin{array}{l}\text { U.o. } \\
\text { (17) }\end{array}$ & $\begin{array}{l}\text { U.o. } \\
\text { (18) }\end{array}$ & $\begin{array}{l}\text { U.o. } \\
\text { (19) }\end{array}$ & $\begin{array}{l}\text { U.o. } \\
\text { (20) }\end{array}$ & $\begin{array}{l}\text { U.a. } \\
\text { (21) }\end{array}$ & $\begin{array}{l}\text { U.a. } \\
\text { (22) }\end{array}$ & $\begin{array}{l}\text { U.a. } \\
\text { (23) }\end{array}$ & $\begin{array}{l}\text { U.a. } \\
\text { (24) }\end{array}$ & $\begin{array}{l}\text { U.m. } \\
\text { (25) }\end{array}$ & $\begin{array}{l}\text { U.m. } \\
\text { (26) }\end{array}$ & $\begin{array}{l}\text { U.m. } \\
\text { (27) }\end{array}$ & $\begin{array}{l}\text { U.m. } \\
\text { (28) }\end{array}$ \\
\hline 4.11 & 3 & 24 & & & & & & & & & & & & & & & & & & & & & & & & & & \\
\hline 5.46 & 9 & 17 & & & & & & & & & & & & & & & & & & & & & & & & & & \\
\hline 5.64 & 6 & 18 & & & & & & & & & & & & & & & & & & & & & & & & & & \\
\hline 6.05 & 2 & 6 & 18 & & & & & & & & & & & & & & & & & & & & & & & & & \\
\hline 6.51 & 9 & 17 & 16 & & & & & & & & & & & & & & & & & & & & & & & & & \\
\hline 6.81 & 9 & 17 & 16 & 22 & & & & & & & & & & & & & & & & & & & & & & & & \\
\hline 6.85 & 2 & 6 & 18 & 3 & 24 & & & & & & & & & & & & & & & & & & & & & & & \\
\hline 7.12 & 2 & 6 & 18 & 3 & 24 & 10 & & & & & & & & & & & & & & & & & & & & & & \\
\hline 7.21 & 2 & 6 & 18 & 3 & 24 & 10 & 19 & 21 & & & & & & & & & & & & & & & & & & & & \\
\hline 7.46 & 2 & 6 & 18 & 3 & 24 & 10 & 19 & 21 & 9 & 17 & 16 & 22 & & & & & & & & & & & & & & & & \\
\hline 7.72 & 8 & 20 & & & & & & & & & & & & & & & & & & & & & & & & & & \\
\hline 8.20 & 15 & 27 & & & & & & & & & & & & & & & & & & & & & & & & & & \\
\hline 8.55 & 12 & 14 & & & & & & & & & & & & & & & & & & & & & & & & & & \\
\hline 8.63 & 2 & 6 & 18 & 3 & 24 & 10 & 19 & 21 & 9 & 17 & 16 & 22 & 8 & 20 & & & & & & & & & & & & & & \\
\hline 8.64 & 1 & 4 & 2 & 6 & 18 & 3 & 24 & 10 & 19 & 21 & 9 & 17 & 16 & 22 & 8 & 20 & & & & & & & & & & & & \\
\hline 9.06 & 1 & 4 & 2 & 6 & 18 & 3 & 24 & 10 & 19 & 21 & 9 & 17 & 16 & 22 & 8 & 20 & 23 & & & & & & & & & & & \\
\hline 9.75 & 1 & 4 & 2 & 6 & 18 & 3 & 24 & 10 & 19 & 21 & 9 & 17 & 16 & 22 & 8 & 20 & 23 & 5 & 7 & & & & & & & & & \\
\hline 9.78 & 1 & 4 & 2 & 6 & 18 & 3 & 24 & 10 & 19 & 21 & 9 & 17 & 16 & 22 & 8 & 20 & 23 & 5 & 7 & 28 & & & & & & & & \\
\hline 9.85 & 1 & 4 & 2 & 6 & 18 & 3 & 24 & 10 & 19 & 21 & 9 & 17 & 16 & 22 & 8 & 20 & 23 & 5 & 7 & 28 & 13 & & & & & & & \\
\hline 10.16 & 12 & 14 & 25 & & & & & & & & & & & & & & & & & & & & & & & & & \\
\hline 11.00 & 1 & 4 & 2 & 6 & 18 & 3 & 24 & 10 & 19 & 21 & 9 & 17 & 16 & 22 & 8 & 20 & 23 & 5 & 7 & 28 & 13 & 12 & 14 & 25 & & & & \\
\hline 12.24 & 11 & 15 & 27 & & & & & & & & & & & & & & & & & & & & & & & & & \\
\hline 12.29 & 1 & 4 & 2 & 6 & 18 & 3 & 24 & 10 & 19 & 21 & 9 & 17 & 16 & 22 & 8 & 20 & 23 & 5 & 7 & 28 & 13 & 12 & 14 & 25 & 11 & 15 & 27 & \\
\hline 19.42 & 1 & 4 & 2 & 6 & 18 & 3 & 24 & 10 & 19 & 21 & 9 & 17 & 16 & 22 & 8 & 20 & 23 & 5 & 7 & 28 & 13 & 12 & 14 & 25 & 11 & 15 & 27 & 26 \\
\hline
\end{tabular}

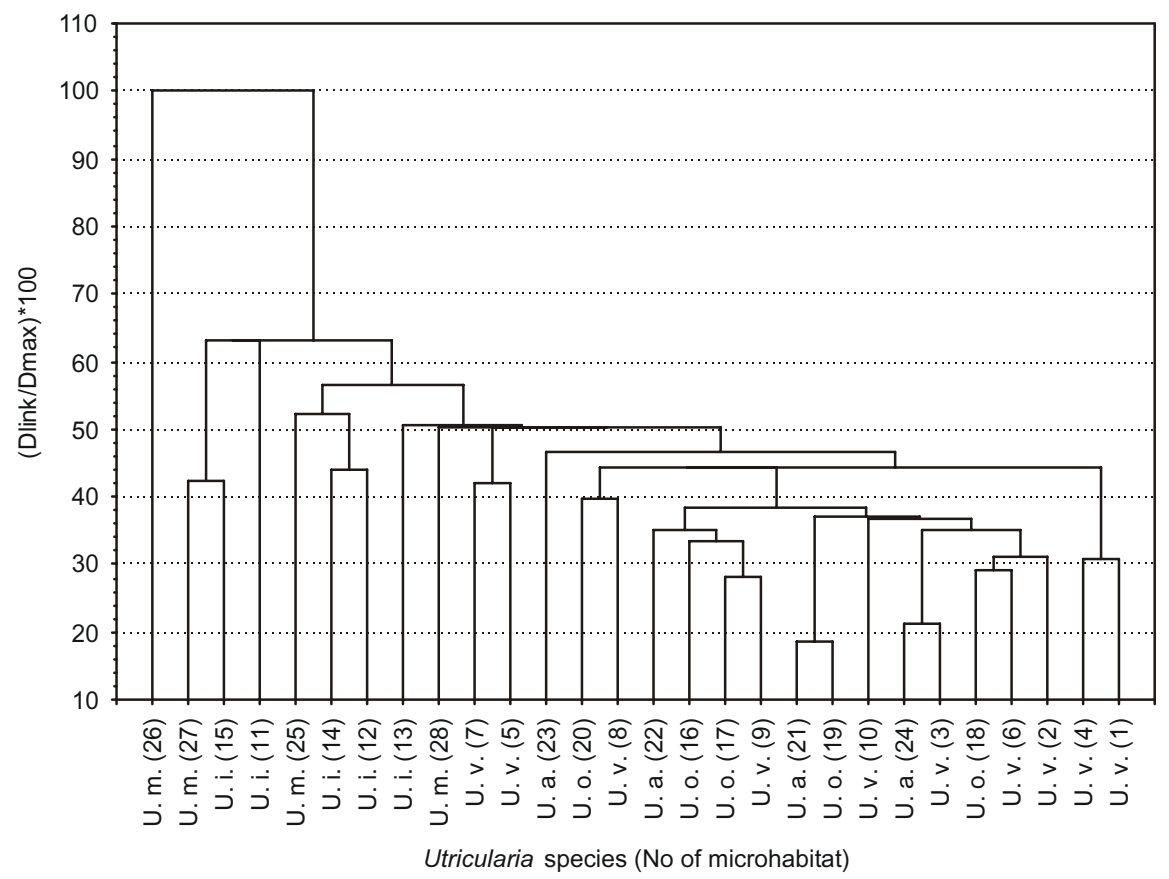

Fig. 9. Hierarchical tree plot of microhabitats similarity of the Utricularia species examined. mical properties can survive in sites of high differentiation of water properties, and $U$. vulgaris is particularly just such a species.

Ecological studies of water ecosystems are valuable tests (Malty, Dugan 1994). The results of this type of investigations should be taken into account in active protection of plants, cultivation and protection of their biotopes (Kosiba 1992b, c, 1995).

\section{LITERATURE CITED}

BOYD E.C. 1968 Some aspects of aquatic plant ecology. Reservoir Fishery Rescurces Symposium Athens, April 5-7, Athens. Georgia, Washington, D.C. Fish. Soc. pp. 114-129.

BREJ T. 1998. Heavy metal tolerance in Agropyron repens (L.) P. Bauv. populations from the Legnica copper smelter area, Lower Silesia. Acta Soc. Bot. Pol. 67: 325-333. 
FABISZEWSKI J., KWIATKOWSKI P. 1997. Wymarłe i wymierające rośliny Sudetów. Annales Silesiae, 27: 9-29 (in Polish with English summary).

FABISZEWSKI J., BREJ T. 2000. Contemporary habitat and floristic changes in the Sudety Mts. Acta Soc. Bot. Pol. 69: 215-222.

FABISZEWSKI J., KWIATKOWSKI P. 2002. Threatened vascular plants of the Sudeten Mountains. Acta Soc. Bot. Pol. 71 (4): 339-350

HERMANOWICZ W., DOJLIDO J., DOŻANSKA W., KOZIOROWSKI B., ZERZE J. 1999. Fizyczno-chemiczne badanie wody i ścieków. Arkady, Warszawa (in Polish).

HERPIN U., BERLEKAMP J., MARKERT B., WOLTERBEEK B., GRODZINSKA K., SIEWERS U., LIETH H., WECKERT V. 1996. The distribution of heavy metals in a transect of the three states the Netherlands, Germany and Poland, determined with the aid of moss monitoring. The Science of the Total Environment, 187: 185-198.

HUTCHINSON E.G. 1975. A treatise on limnology. Vol. III, Limnological botany. Jon Wiley and Sons, New York-London-Sydney-Toronto.

KAŹMIERCZAKOWA R., ZARZYCKI K. (eds). 2001. Polska czerwona księga roślin. Paprotniki i rośliny kwiatowe. Instytut Botaniki im. W. Szafera PAN, Instytut Ochrony Przyrody PAN, Kraków (in Polish with English summary).

KĄCKI Z. (ed.). 2003. Zagrożone gatunki flory naczyniowej Dolnego Śląska (Endangered vascular plants of Lower Silesia). Instytut Biologii Roślin, Uniwersytet Wrocławski, Polskie Towarzystwo Przyjaciół Przyrody „Pro Natura”, Wrocław (in Polish with English summary).

KOSIBA P., SAROSIEK J. 1989. Stanowisko Utricularia intermedia Hayne i Utricularia minor L. w Strzybnicy koło Tarnowskich Gór. Acta Universitatis Wratislaviensis, No 973, Prace Botaniczne, 39: 71-78 (in Polish with English summary).

KOSIBA P. 1990. Pływacze Utricularia spp. - rośliny ginące. Chrońmy Przyrodę Ojczystą, 2-3: 57-62. (in Polish with English summary).

KOSIBA P. 1992a. Studies on the ecology of Utricularia vulgaris L., I. Ecological differentiation of Utricularia vulgaris L. population affected by chemical factors of the habitat. Ekologia Polska, 40, 2: 147-192.

KOSIBA P. 1992b. Studies on the ecology of Utricularia vulgaris L., II. Phisical, chemical and biotic factors and the growth of Utricularia vulgaris L. in cultures in vitro. Ekologia Polska, 40, 2: 193-212.

KOSIBA P. 1992c. Wymagania siedliskowe Utricularia minor L. i uprawa zachowawcza tej rośliny w Ogrodzie Botanicznym we Wrocławiu. Biuletyn Ogrodów Botanicznych Muzeów i Zbiorów, Ogród Botaniczny Polskiej Akademii Nauk, Warszawa-Powsin, 1: 47-52 (in Polish with English summary).

KOSIBA P. 1993. Ekologiczna charakterystyka populacji Utricularia ochroleuca Hartmann i Utricularia neglecta Lehmann oraz warunków ich występowania w Węglińcu. Acta Universitatis Wratislaviensis, No 1443, Prace Botaniczne, 52: 25-32 (in Polish with English summary).

KOSIBA P. 1995. Uprawa zachowawcza Utricularia intermedia Hayne w Ogrodzie Botanicznym we Wrocławiu. Biuletyn Ogrodów Botanicznych Muzeów i Zbiorów, Ogród Botaniczny Polskiej Akademii Nauk, Warszawa-Powsin, 4: 5-10 (in Polish with English summary).

LEGENDRE P., LEGENDRE L. 1998. Numerical ecology. 2nd English edition. Elsevier Science BV, Amsterdam.

MALTY E., DUGAN P.J. 1994. Wetland ecosystem protection, management, and restoration: an international perspective. In: Davis S.M., Ogden J.C. (eds) Everglades: The Ecosystem and its Restoration. St. Lucie Press, Delray Beach, FL., USA, pp. 29-46.

MIREK Z., PIEKKOŚ-MIRKOWA H., ZAJAC A., ZAJAC M. 2002. Flowering plants and pteridophytes of Poland. A checklist. (Krytyczna lista roślin naczyniowych Polski). W. Szafer Institute of Botany, Polish Academy of Sciences, Kraków (in Polish with English summary).

MOISEENKO T.I., SANDIMIROV S.S., KUDRYAVTSEVA L.P. 2001. Eutrophication of Surface Water in the Arctic Region. Water Resources, 28, 3: 307-316.

MURPHY K. J. 2002. Plant communities and plant diversity in softwater lakes of northern Europe. Aquatic Botany, 73: 287-324.

NOWAK A., SPAŁEK K. (eds). 2002. Czerwona księga roślin województwa opolskiego. Rośliny naczyniowe wymarłe, zagrożone i rzadkie. Opol. Tow. Przyj. Nauk, Opole (in Polish with English summary).

PIP E. 1979. Survey of the ecology of submerged aquatic macrophytes in central Canada. Aquat. Bot. 7: 339-357.

PIP E. 1984. Ecogeographical tolerance range variation in aquatic macrophytes. Hydrobiologia. 108: 37-48.

ROMAN C.T., BARRETT N.E., PORTNOY J.W. 2001. Aquatic vegetation and trophic condition of Cape Cod (Massachusetts, U.S.A.) kettle ponds. Hydrobiologia, 443: 31-42.

ROY S., IHANTOLA R., HANNINEN O. 1992 Peroxidase activity in lake macrophytes and its relation to pollution tolerance. Environmental and Experimental Botany, 32, 4: 457-464.

SEDDON B. 1972. Aquatic macrophytes as limnological indicators. Freshwat. Biol. 2: 107-130.

SMITH V.H., TILMAN G.D., NEKOLA J.C. 1999. Eutrophication: impacts of excess nutrient input on freshwater, marine, and terrestrial ecosystems. Environmental Pollution, 100: 179-196.

STATSOFT, Inc. 2003. STATISTICA (data analysis software system), version 6. (www.statsoft.com.), StatSot, Inc., Tulsa, OK.

VEZJAK M., SAVSEK T., STUHLER E. A. 1998. System dynamice of eutrophication processes in lakes. Eur. J. Operational Res., 109: 442-451.

WETZEL R.G. 1983. Limnology. Saunders College Publishing, Philadelphia, PA, USA.

WIEGLEB G. 1978a. Untersuchungen über den Zusammenhang zwischen hydrochemischen Umweltfaktoren und Makrophytenvegetation in stehenden Gewässern. Arch. Hydrobiol. 83: 443-484.

WIEGLEB G. 1978b. Vergleich ökologischer und soziologischer Artengruppen von Makrophyten des Süßwassers. Verh. Ges. Ökol., Kiel, pp. 243-249.

WIEGLEB G. 1981. Application of multiple discriminant analysis of the correlation between macrophyte vegetation and water quality in running waters of central Europe. Hydrobiologia, 79: 91-100.

WIEGLEB G., BRUX H., HERR W. 1991. Human impact on the ecological performance of Potamogeton species in northwestern Germany. Vegetatio, 97: 161-172.

ZAJĄC K. 1994. Zarys metod statystycznych. PWE, Warszawa (in Polish).

ZAJĄC A., ZAJĄC M. (eds). 2001. Distribution atlas of vascular plants in Poland. Edited by Laboratory of Computer Chronology, Institute of Botany, Jagiellonian University, Cracow (in Polish with English summary).

ZARZYCKI K., WOJEWODA W., HEINRICH Z (eds). 1992. Lista roślin zagrożonych w Polsce. 2nd ed. PAN, Instytut Botaniki im. W. Szafera, Kraków (in Polish with English summary).

ŻUKOWSKI W. 1974. Rozmieszczenie gatunków z rodzaju Utricularia L. w Polsce. Bad. Fizjogr. Pol. Zach., B, 27: 189-217 (in Polish). 